\section{Joint effect of paid working hours and multiple job holding on work absence due to health problems among basic education teachers in Brazil: the Educatel Study}

\author{
Efecto conjunto de las horas de trabajo \\ remunerado y el pluriempleo sobre la ausencia al \\ trabajo por problemas de salud en profesores de \\ educacuión básica en Brasil: el Estudio Educatel
}

\author{
Efeito conjunto das horas de trabalho \\ remunerado e de múltiplos empregos sobre \\ o absenteísmo por motivo de saúde entre \\ professores de ensino básico no Brasil: \\ Estudo Educatel
}

Lucía Rodríguez-Loureiro 1,2,3

Lucía Artazcoz 1,2,4,5

María López-Ruiz 1,2,3,6

Ada Ávila Assunção 7

Fernando G. Benavides 1,2,3

doi: $10.1590 / 0102-311 \times 00081118$

\begin{abstract}
The objectives were to assess the joint effect of working hours paid per week and multiple job holding on sickness absence, by sex, among basic education teachers in Brazil. This study is based on a survey carried out over a representative sample of 5,116 active basic education teachers in Brazil between 2015 and 2016 (Educatel Study). We created a dummy variable to assess the joint effect of weekly paid working hours [standard (35-40 hours); part-time (<35 hours); moderately long (41-50 hours); and very long (> 50 hours)] and multiple job holding (working in several schools - no/yes). Working 35-40 hours in one school was the reference category. We conducted Poisson regression models with robust variance to obtain prevalence ratios $(P R)$ and $95 \%$ confidence intervals (95\%CI) of the association with self-certified sickness absence and medically certified sickness absence. Models were adjusted for age, type of contract and salary, and stratified by sex. Significant associations with sickness absence were only found among teachers working in more than one school. Associations with self-certified sickness absence were found among women with standard and men with moderately long working hours, and for both women and men working > 50 hours (PR: 1.21, 95\%CI: 1.09-1.35; PR: 1.40, 95\%CI: 1.18-1.66; respectively). Associations with medically certified sickness absence were found among teachers working $>50$ hours, among women (PR: 1.30, 95\%CI: 1.03-1.63) and men (PR: 1.41, 95\%CI: 1.04-1.92). Teachers working longer hours in several schools could be suffering health problems, deriving in work absence.
\end{abstract}

School Teachers; Occupational Health; Absenteeism; Socioeconomic Factors

\author{
Correspondence \\ L. Rodríguez-Loureiro \\ Centro de Investigación en Salud Laboral, Universitat Pompeu \\ Fabra. \\ Edificio PRBB, C/Dr. Aiguader, 88, Barcelona / Barcelona - \\ 08003, España. \\ Irloureiro92@gmail.com \\ 1 Centro de Investigación en Salud Laboral, Universitat Pompeu \\ Fabra, Barcelona, España. \\ 2 Centro de Investigación Biomédica en Red - Epidemiología y \\ Salud Pública, Madrid, España. \\ 3 Instituto Hospital del Mar de Investigaciones Médicas, \\ Barcelona, España. \\ 4 Agència de Salut Pública de Barcelona, Barcelona, España. \\ 5 Institut d'Investigació Biomèdica de Sant Pau, Barcelona, \\ España. \\ 6 Facultad Latinoamericana de Ciencias Sociales, Salamanca, \\ España. \\ ${ }^{7}$ Faculdade de Medicina, Universidade Federal de Minas \\ Gerais, Belo Horizonte, Brasil.
}




\section{Introduction}

The relationship between long working hours and health status has been extensively assessed in the literature. A recent systematic review reported associations between working over 40 hours weekly and a range of health outcomes. Although long working hours could lead to certain health problems, such as cardiovascular disease, diabetes, anxiety, depression or disability 1,2,3,4, findings are still contradictory 5. Thus, despite most studies have found consistent associations with working $\geq 55$ hours weekly, results for moderately long working hours are still inconsistent 3 . Moreover, differences among countries have been reported 6,7.

In contrast, the effect of multiple job holding on health status has been scarcely studied. Studies in the United States have observed a higher risk of injuries and less sleep among multiple job-holders 8,9, while a study conducted in Denmark found no associations of multiple job holding with long-term sickness absence 10. Also, although the effect of working hours in this association has been discussed, its joint effect with multiple job holding has not been thoroughly assessed.

Additionally, gender division of labor strongly determines the time allocated to paid work: whereas men tend to work longer hours due to their breadwinner role, women frequently work part-time, since they usually assume more care responsibilities. Hence, working longer hours or moonlighting could have a stronger impact on women's health due to the combination of paid and family work 11,12. Therefore, although most previous research was based on men-only samples or did not separate the analysis by sex ${ }^{3}$, any analysis of the relationship between working hours or multiple job holding and health status should be separated by sex and consider gender roles.

In Brazil, the intensification of teachers' work derived from the reforms in education has gradually become a matter of concern ${ }^{13}$. In 2008 , the legal regulation established the implementation of an extra-class working day, exclusive dedication of the teachers to one school and better salaries, which represent important improvement for the quality of the school as well as for working and employment conditions 14. Regarding work hours in the main job among Brazilian teachers, there has been a reverse in the downward trend observed between 2002 and 2006; and the proportion in the range of 36 to 40 weekly hours, which represented 32\% in 2006, increased to 39\% in 2011 and to $41 \%$ in 2013 15. Although this tendency coincides in time with the implementation of the new legislation, according to recent reports, these findings are not attributable to the law reform, but to the need of salary increases or the lack of teachers in a given educational network 16 .

The 2013 Teaching and Learning International Survey (TALIS) showed that Brazilian teachers spent 25 weekly hours teaching, exceeding in 6 hours the average of the Organization for Economic Cooperation and Development (OECD). Brazil had also one of the larger class sizes, with more than 30 students in each class, and one of the highest student-teachers ratio 17. Regarding exclusive dedication, a study conducted in seven Brazilian states showed that the proportion of basic education teachers working in several schools reached $62 \%$ among secondary education teachers, $49 \%$ among teachers of primary education and $28 \%$ among teachers of childhood education 18 . It should be taken into account that the teacher's exclusive dedication to one school improves the student's attainment 19.

As far as we know, there are no studies about the joint association of working hours and multiple job holding with sickness absence. Therefore, the aim of this study was to assess the relationship between the combination of multiple job holding and weekly paid working hours with work absence due to health problems and to examine potential gender differences among basic education teachers in Brazil.

\section{Methods}

\section{Study design}

This cross-sectional study uses the information from the Educatel Study, a phone survey conducted over a representative sample of basic education teachers, held between October 2015 and March 2016 in Brazil. Briefly, as it has already been described 20, the information of the survey was extended using the registries of the Research Institute of the Brazilian Ministry of Education and Culture. Prefer- 
ably, the contact with the participant was made through the telephone number of the school and the interview was carried out in the participants' workplace.

\section{Study population and sample}

The survey provides information about 6,510 basic education teachers aged 18 or older who were active the year before the questionnaire administration. Only active teachers at the time of the interview were included in the study $(\mathrm{n}=5,116)$. The survey presented an $85 \%$ response rate 20 .

\section{Variables}

Work absence was measured by asking the respondents if they had been absent from work for at least one day in the last 12 months because of a health problem. If they answered affirmatively, the respondents were subsequently asked if a doctor had evaluated the health problem and certified the absence. Two dichotomous variables (yes/no) were analyzed: (i) self-certified sickness absence; (ii) medically certified sickness absence. Self-reported work absence due to health problems, measured as having lost at least one day of work due to illness in the past 12 months, is used as a valid indicator to assess the prevalence of sickness absence among countries 21 . In countries with official registries, several studies have proven its comparability with administrative databases 22 . In fact, in the Whitehall II Study, sickness absence was conceptualized as an integrate health indicator, regardless of whether it is medically certified or self-notified 23 . Using self-reported data on work absence due to health problems is a reliable alternative when official registries are lacking.

The predictor variables were working in more than one school ("no", "yes") and weekly paid working hours (categorized into "35-40h" as standard working hours", “<35h" as part-time, "41-50h" as moderately long working hours, and " $>50 \mathrm{~h}$ " as very long working hours), including the total hours working in each school. To thoroughly explore the interaction between them, the joint effect analysis proposed by Szklo \& Nieto 24 was performed. A dummy variable was created to assess the combination of the two variables, examining the effect of the different subgroups on the health outcomes in comparison with the reference category: working 35-40 weekly hours in one school.

The adjustment variables were age (“ $\leq 34$ years”, "35-44 years”; “45-54 years”; " $\geq 55$ years"), type of contract ("Public administration: Permanent/Temporary”; "Private administration: Permanent/ Temporary”) and salary (“<2 minimum wages”, “2-3 minimum wages”, “> 3 minimum wages”).

\section{Statistical analysis}

First, several bivariate analyses were performed to estimate the number and percentage of each study variable by sex, and to estimate the number and percentage of each study variable according to the main explicative variable by sex. Poisson regression models with robust variance were conducted to obtain crude and adjusted prevalence ratios (PR) and their 95\% confidence intervals (95\%CI) regarding the association between the joint effect of working in more than one school and weekly paid working hours on the self-certified sickness absence and medically certified sickness absence. Analyses were stratified by sex. All analyses were performed with the statistical program Stata, version 13 (https://www.stata.com).

\section{Results}

The general description of the sample is displayed in Table 1, showing that women had a higher prevalence of self-certified sickness absence than men (54\% and 45\%, respectively), although this difference decreased for medically certified sickness absence (21\% and $19 \%$, respectively). Women worked more frequently standard working hours than men (35-40 hours weekly) and in exclusive dedication to one school.

Tables 2 and 3 show the distribution of the outcomes and the predictor variables according to the composite variable. Among both sexes, the highest prevalence of work absence due to health problems 
Table 1

General description of the sample, by sex. Educatel Study, 2015-2016.

\begin{tabular}{|c|c|c|c|c|}
\hline \multirow[t]{2}{*}{ Study variables } & \multicolumn{2}{|c|}{ Women } & \multicolumn{2}{|c|}{ Men } \\
\hline & $\mathbf{n}$ & $\%$ & $\mathbf{n}$ & $\%$ \\
\hline \multicolumn{5}{|c|}{ Number of schools and weekly paid working hours } \\
\hline \multicolumn{5}{|l|}{ Working in one school (hours) } \\
\hline $35-40$ & 823 & 25.6 & 353 & 18.6 \\
\hline$<30$ & 935 & 29.0 & 480 & 25.3 \\
\hline $41-50$ & 55 & 1.7 & 31 & 1.6 \\
\hline$>50$ & 47 & 1.5 & 22 & 1.2 \\
\hline \multicolumn{5}{|c|}{ Working in more than one school (hours) } \\
\hline $35-40$ & 530 & 16.5 & 328 & 17.3 \\
\hline$<30$ & 292 & 9.1 & 219 & 11.6 \\
\hline $41-50$ & 232 & 7.2 & 191 & 10.1 \\
\hline$>50$ & 306 & 9.5 & 272 & 14.3 \\
\hline Self-certified sickness absence & 1,740 & 54.0 & 848 & 44.7 \\
\hline Medically certified sickness absence & 684 & 21.2 & 356 & 18.8 \\
\hline \multicolumn{5}{|l|}{ Age (years) } \\
\hline$\leq 34$ & 992 & 30.8 & 643 & 33.9 \\
\hline $35-44$ & 982 & 30.5 & 588 & 31.0 \\
\hline $45-54$ & 895 & 27.8 & 442 & 23.3 \\
\hline$>55$ & 351 & 10.9 & 223 & 11.8 \\
\hline \multicolumn{5}{|l|}{ Type of contract } \\
\hline \multicolumn{5}{|l|}{ Public school } \\
\hline Permanent & 1,388 & 43.1 & 632 & 33.3 \\
\hline Temporary & 521 & 16.2 & 293 & 15.5 \\
\hline \multicolumn{5}{|l|}{ Private school } \\
\hline Permanent & 806 & 25.0 & 675 & 35.6 \\
\hline Temporary & 505 & 15.7 & 296 & 15.6 \\
\hline \multicolumn{5}{|l|}{ Salary (minimum wages) * } \\
\hline$<2$ & 1,233 & 38.3 & 593 & 31.3 \\
\hline $2-3$ & 931 & 28.9 & 427 & 22.6 \\
\hline$>3$ & 1052 & 32.7 & 872 & 46.1 \\
\hline Total & 3,220 & 100.0 & 1,896 & 100.0 \\
\hline
\end{tabular}

* The variable salary has 4 missing values among women (0.1\%) and 4 missing values among men $(0.2 \%)$.

was found among teachers working more than 50 hours in more than one school, being slightly higher among women than among men (for self-certified sickness absence: 64\% and 57\%, respectively; for medically certified sickness absence: $28 \%$ and $25 \%$, respectively). Teachers working in several schools were more frequently hired in a private school with a permanent contract, especially among men. Besides, the proportion of teachers earning $\geq 3$ minimum wages was much higher when working in one school compared to those working the same weekly hours in different schools.

The association between the composite variable and self-certified sickness absence, by sex, is shown in Table 4. Among women, working part-time was negatively associated with work absence due to health problems, although these associations were not significant after adjustment. Women working in more than one school had a higher probability of experiencing self-certified sickness absence, both if they worked weekly 35-40 hours (PRa: 1.17, 95\%CI: 1.07-1.29) and > 50 hours (PRa: 1.21, 95\%CI: 1.09-1.35). Among men, there was a positive and significant association for those working in several schools 41-50 hours (PRa: 1.35 , 95\%CI: 1.12-1.63) and > 50 hours weekly (PRa: 1.40, 95\%CI: 1.18-1.66). 
Table 2

Distribution of outcome and explicative variables according to the number of schools and weekly hours worked. Women. Educatel Study, $2015-2016$.

\begin{tabular}{|c|c|c|c|c|c|c|c|c|c|c|c|c|c|c|c|c|}
\hline \multirow[t]{3}{*}{ Study variables } & \multicolumn{8}{|c|}{ Working in one school } & \multicolumn{8}{|c|}{ Working in more than one school } \\
\hline & \multicolumn{2}{|c|}{$35-40$ hours } & \multicolumn{2}{|c|}{$<35$ hours } & \multicolumn{2}{|c|}{ 41-50 hours } & \multicolumn{2}{|c|}{$>50$ hours } & \multicolumn{2}{|c|}{$35-40$ hours } & \multicolumn{2}{|c|}{$<35$ hours } & \multicolumn{2}{|c|}{ 41-50 hours } & \multicolumn{2}{|c|}{$>50$ hours } \\
\hline & $\mathbf{n}$ & $\%$ & $\mathbf{n}$ & $\%$ & $\mathbf{n}$ & $\%$ & $\mathbf{n}$ & $\%$ & $\mathbf{n}$ & $\%$ & $\mathbf{n}$ & $\%$ & $\mathbf{n}$ & $\%$ & $\mathbf{n}$ & $\%$ \\
\hline $\begin{array}{l}\text { Self-certified sickness } \\
\text { absence }\end{array}$ & 437 & 53.1 & 450 & 48.1 & 28 & 50.9 & 28 & 59.6 & 326 & 61.5 & 141 & 48.3 & 135 & 58.2 & 195 & 63.7 \\
\hline $\begin{array}{l}\text { Medically certified } \\
\text { sickness absence }\end{array}$ & 181 & 22.0 & 161 & 17.2 & 11 & 20.0 & 11 & 23.4 & 121 & 22.8 & 58 & 19.9 & 55 & 23.7 & 86 & 28.1 \\
\hline \multicolumn{17}{|l|}{ Age (years) } \\
\hline$\leq 34$ & 244 & 29.6 & 287 & 30.7 & 18 & 32.7 & 17 & 36.2 & 169 & 31.9 & 99 & 33.9 & 78 & 33.6 & 80 & 26.1 \\
\hline $35-44$ & 273 & 33.2 & 254 & 27.2 & 18 & 32.7 & 9 & 19.1 & 178 & 33.6 & 80 & 27.4 & 83 & 35.8 & 87 & 28.4 \\
\hline $45-54$ & 211 & 25.6 & 270 & 28.9 & 11 & 20.0 & 13 & 27.7 & 143 & 27.0 & 81 & 27.7 & 61 & 26.3 & 105 & 34.3 \\
\hline$>55$ & 95 & 11.5 & 124 & 13.3 & 8 & 14.5 & 8 & 17.0 & 40 & 7.5 & 32 & 11.0 & 10 & 4.3 & 34 & 11.1 \\
\hline \multicolumn{17}{|l|}{ Type of contract } \\
\hline \multicolumn{17}{|l|}{ Public school } \\
\hline Permanent & 444 & 53.9 & 383 & 41.0 & 21 & 38.2 & 27 & 57.4 & 223 & 42.1 & 81 & 27.7 & 78 & 33.6 & 131 & 42.8 \\
\hline Temporary & 131 & 15.9 & 209 & 22.4 & 9 & 16.4 & 6 & 12.8 & 71 & 13.4 & 51 & 17.5 & 23 & 9.9 & 21 & 6.9 \\
\hline \multicolumn{17}{|l|}{ Private school } \\
\hline Permanent & 94 & 11.4 & 117 & 12.5 & 10 & 18.2 & 6 & 12.8 & 202 & 38.1 & 121 & 41.4 & 115 & 49.6 & 141 & 46.1 \\
\hline Temporary & 154 & 18.7 & 226 & 24.2 & 15 & 27.3 & 8 & 17.0 & 34 & 6.4 & 39 & 13.4 & 16 & 6.9 & 13 & 4.2 \\
\hline \multicolumn{17}{|l|}{ Salary (minimum } \\
\hline \multicolumn{17}{|l|}{ wages) } \\
\hline$<2$ & 182 & 22.2 & 447 & 47.9 & 14 & 25.5 & 14 & 29.8 & 231 & 43.7 & 155 & 53.1 & 98 & 42.2 & 92 & 30.1 \\
\hline $2-3$ & 252 & 30.7 & 248 & 26.6 & 11 & 20.0 & 17 & 36.2 & 171 & 32.3 & 80 & 27.4 & 62 & 26.7 & 90 & 29.4 \\
\hline$>3$ & 387 & 47.1 & 239 & 25.6 & 30 & 54.5 & 16 & 34.0 & 127 & 24.0 & 57 & 19.5 & 72 & 31.0 & 124 & 40.5 \\
\hline Total & 823 & 100.0 & 935 & 100.0 & 55 & 100.0 & 47 & 100.0 & 530 & 100.0 & 292 & 100.0 & 232 & 100.0 & 306 & 100.0 \\
\hline
\end{tabular}

Finally, Table 5 shows the association between the composite variable and medically certified sickness absence, by sex. For both women and men, associations were found among those working in more than one school and > 50 weekly hours (PRa: 1.30, 95\%CI: 1.03-1.63; PRa: 1.41, 95\%CI: 1.041.92; respectively).

\section{Discussion}

This study assessing the joint effect of weekly paid working hours and multiple job holding on work absence due to health problems among basic education teachers in Brazil produced three main findings. First, we only found an association between working hours and self-certified/medically certified sickness absence among teachers working in more than one school. Second, women working standard hours and men working moderately long hours in more than one school were more likely to have self-certified sickness absence. Lastly, for both women and men, to work very long weekly hours in more than one school was positively associated with self-certified and medically certified sickness absence.

Our findings suggest an increased likelihood of being absent from work due to health problems only among Brazilian teachers working in several schools. Consistent with previous research 10, there seems to be an interaction between multiple job holding and long working hours, resulting in an increased risk for work absence due to health problems. However, when considering exclusively multiple job holding, the aforementioned study found no associations with long-term sickness absence. In 
Table 3

Distribution of outcome and explicative variables according to the number of schools and weekly hours worked. Men. Educatel Study, 2015-2016.

\begin{tabular}{|c|c|c|c|c|c|c|c|c|c|c|c|c|c|c|c|c|}
\hline \multirow[t]{3}{*}{ Study variables } & \multicolumn{8}{|c|}{ Working in one school } & \multicolumn{8}{|c|}{ Working in more than one school } \\
\hline & \multicolumn{2}{|c|}{$35-40$ hours } & \multicolumn{2}{|c|}{$<35$ hours } & \multicolumn{2}{|c|}{ 41-50 hours } & \multicolumn{2}{|c|}{$>50$ hours } & \multicolumn{2}{|c|}{$35-40$ hours } & \multicolumn{2}{|c|}{$<35$ hours } & \multicolumn{2}{|c|}{ 41-50 hours } & \multicolumn{2}{|c|}{$>50$ hours } \\
\hline & $\mathbf{n}$ & $\%$ & $\mathbf{n}$ & $\%$ & $\mathbf{n}$ & $\%$ & $\mathbf{n}$ & $\%$ & $\mathbf{n}$ & $\%$ & $\mathbf{n}$ & $\%$ & $\mathbf{n}$ & $\%$ & $\mathbf{n}$ & $\%$ \\
\hline $\begin{array}{l}\text { Self-certified sickness } \\
\text { absence }\end{array}$ & 139 & 39.4 & 178 & 37.1 & 13 & 41.9 & 11 & 50.0 & 148 & 45.1 & 101 & 46.1 & 104 & 54.5 & 154 & 56.6 \\
\hline $\begin{array}{l}\text { Medically certified } \\
\text { sickness absence }\end{array}$ & 64 & 18.1 & 72 & 15.0 & 7 & 22.6 & 2 & 9.1 & 59 & 18.0 & 43 & 19.6 & 40 & 20.9 & 69 & 25.4 \\
\hline \multicolumn{17}{|l|}{ Age (years) } \\
\hline$\leq 34$ & 118 & 33.4 & 157 & 32.7 & 9 & 29.0 & 4 & 18.2 & 118 & 36.0 & 83 & 37.9 & 74 & 38.7 & 80 & 29.4 \\
\hline $35-44$ & 108 & 30.6 & 143 & 29.8 & 9 & 29.0 & 7 & 31.8 & 91 & 27.7 & 60 & 27.4 & 61 & 31.9 & 109 & 40.1 \\
\hline $45-54$ & 84 & 23.8 & 106 & 22.1 & 11 & 35.5 & 7 & 31.8 & 85 & 25.9 & 49 & 22.4 & 44 & 23.0 & 56 & 20.6 \\
\hline$>55$ & 43 & 12.2 & 74 & 15.4 & 2 & 6.5 & 4 & 18.2 & 34 & 10.4 & 27 & 12.3 & 12 & 6.3 & 27 & 9.9 \\
\hline \multicolumn{17}{|l|}{ Type of contract } \\
\hline \multicolumn{17}{|l|}{ Public school } \\
\hline Permanent & 161 & 45.6 & 182 & 37.9 & 10 & 32.3 & 13 & 59.1 & 82 & 25.0 & 49 & 22.4 & 47 & 24.6 & 88 & 32.4 \\
\hline Temporary & 70 & 19.8 & 112 & 23.3 & 6 & 19.4 & 2 & 9.1 & 42 & 12.8 & 27 & 12.3 & 17 & 8.9 & 17 & 6.3 \\
\hline \multicolumn{17}{|l|}{ Private school } \\
\hline Permanent & 61 & 17.3 & 68 & 14.2 & 8 & 25.8 & 5 & 22.7 & 174 & 53.0 & 105 & 47.9 & 104 & 54.5 & 150 & 55.1 \\
\hline Temporary & 61 & 17.3 & 118 & 24.6 & 7 & 22.6 & 2 & 9.1 & 30 & 9.1 & 38 & 17.4 & 23 & 12.0 & 17 & 6.3 \\
\hline \multicolumn{17}{|l|}{$\begin{array}{l}\text { Salary (minimum } \\
\text { wages) }\end{array}$} \\
\hline$<2$ & 46 & 13.1 & 168 & 35.1 & 8 & 25.8 & 1 & 4.5 & 122 & 37.2 & 113 & 51.6 & 59 & 30.9 & 76 & 28.0 \\
\hline $2-3$ & 68 & 19.3 & 102 & 21.3 & 2 & 6.5 & 6 & 27.3 & 93 & 28.4 & 46 & 21.0 & 52 & 27.2 & 58 & 21.4 \\
\hline$>3$ & 238 & 67.6 & 208 & 43.5 & 21 & 67.7 & 15 & 68.2 & 113 & 34.5 & 60 & 27.4 & 80 & 41.9 & 137 & 50.6 \\
\hline Total & 353 & 100.0 & 480 & 100.0 & 31 & 100.0 & 22 & 100.0 & 328 & 100.0 & 219 & 100.0 & 191 & 100.0 & 272 & 100.0 \\
\hline
\end{tabular}

addition, despite the limited existing literature, long working hours alone had so far been negatively associated with sickness absence in both women and men 25,26.

There are several plausible interpretations for our findings. Firstly, teachers working in more than one school might have worse working and employment conditions. These teachers might have multiple part-time contracts, which could lead to stressful situations when trying to get full-time workload done or having unpredictable working schedules or lower salaries than teachers with exclusive dedication to one school 27,28. In our sample, we observed remarkable lower salaries among teachers working in more than one school and with the same working hours than teachers with exclusive dedication (Tables 2 and 3). Teaching in Brazil is marked by an expansion of daily work, absence of remuneration for extra-class work and concomitant work in several schools. These conditions might jeopardize the teacher's well-being 29,30,31. Moreover, teachers working in several schools might experience a lack of engagement with the students and a lack of school membership, which could also predispose work absence due to health problems 18 .

Secondly, teachers might be forced to work in more than one school due to financial pressures. In fact, a recent report has attributed to low salaries the increase in working hours among Brazilian teachers 15. Family financial stress has been described as a relevant factor that forces teachers to work longer hours, resulting in poorer health outcomes 32,33 . It is likely that factors leading to working in several jobs or longer hours are non-mutually exclusive. As already suggested for working hours, the choice (voluntary or forced) may be a relevant factor shaping the relationship between multiple job holding and health 6,34,35. Several studies have observed that long working hours could not fully explain the higher risk of injuries and less sleep of workers with multiple job holding 8,9. Another study assessing the relationship between multiple job holding and long-term sickness absence only 


\section{Table 4}

Number, prevalence and association of the joint effect of weekly paid working hours and multiple job holding on self-certified sickness absence, according to sex. Educatel Study, 2015-2016.

\begin{tabular}{|c|c|c|c|c|c|c|}
\hline Main independent variable, by sex & $\mathbf{n}$ & $\%$ & PRc & $95 \% \mathrm{Cl}$ & PRa & $95 \% \mathrm{Cl}$ \\
\hline \multicolumn{7}{|l|}{ Women } \\
\hline \multicolumn{7}{|c|}{ Number of schools and paid working hours } \\
\hline \multicolumn{7}{|l|}{ Working in one school (hours) } \\
\hline $35-40$ & 437 & 53.1 & 1.00 & & 1.00 & \\
\hline$<35$ & 450 & 48.1 & 0.91 & $0.83-0.99$ * & 0.93 & $0.85-1.02$ \\
\hline $41-50$ & 28 & 50.9 & 0.96 & $0.73-1.25$ & 0.98 & $0.75-1.28$ \\
\hline$>50$ & 28 & 59.6 & 1.12 & $0.88-1.43$ & 1.11 & $0.87-1.43$ \\
\hline \multicolumn{7}{|c|}{ Working in more than one school (hours) } \\
\hline $35-40$ & 326 & 61.5 & 1.16 & $1.06-1.27 * *$ & 1.17 & $1.07-1.29 * * *$ \\
\hline$<35$ & 141 & 48.3 & 0.91 & $0.79-1.04$ & 0.95 & $0.83-1.09$ \\
\hline $41-50$ & 135 & 58.2 & 1.10 & $0.97-1.24$ & 1.11 & $0.98-1.27$ \\
\hline$>50$ & 195 & 63.7 & 1.20 & $1.08-1.33 * * *$ & 1.21 & $1.09-1.35 * * *$ \\
\hline \multicolumn{7}{|l|}{ Men } \\
\hline \multicolumn{7}{|c|}{ Number of schools and paid working hours } \\
\hline \multicolumn{7}{|l|}{ Working in one school (hours) } \\
\hline $35-40$ & 139 & 39.4 & 1.00 & & 1.00 & \\
\hline$<35$ & 178 & 37.1 & 0.94 & $0.79-1.12$ & 0.97 & $0.81-1.15$ \\
\hline $41-50$ & 13 & 41.9 & 1.06 & $0.69-1.64$ & 1.08 & $0.70-1.66$ \\
\hline$>50$ & 11 & 50.0 & 1.27 & $0.82-1.97$ & 1.27 & $0.82-1.96$ \\
\hline \multicolumn{7}{|c|}{ Working in more than one school (hours) } \\
\hline $35-40$ & 148 & 45.1 & 1.15 & $0.96-1.37$ & 1.13 & $0.95-1.36$ \\
\hline$<35$ & 101 & 46.1 & 1.17 & $0.97-1.42$ & 1.18 & $0.97-1.43$ \\
\hline $41-50$ & 104 & 54.5 & 1.38 & $1.15-1.66 * * *$ & 1.35 & $1.12-1.63 * *$ \\
\hline$>50$ & 154 & 56.6 & 1.44 & $1.22-1.70 * * *$ & 1.40 & $1.18-1.66 * * *$ \\
\hline
\end{tabular}

95\% Cl: 95\% confidence interval; PRa: adjusted prevalence ratio (for age, type of contract and salary);

PRc: crude prevalence ratio.

* p-value < 0.05;

** $\mathrm{p}$-value $<0.01$

*** p-value $<0.001$.

found associations among employees with multiple jobs working longer than 37 weekly hours. However, there were no interactions with working hours among workers with second jobs as selfemployed 10. A possible hypothesis for our results would be that Brazilian teachers are a highly homogeneous group, presenting similar incentives to work in several schools. Additionally, their condition of salaried workers might reduce their flexibility to balance work and family demands.

Thirdly, there might be a different management of time use among teachers working in different schools compared to those working in one school. Prior research has evinced that multiple job holders seem to have longer commuting hours and less leisure and rest time. Additionally, they seemed to allocate time during the weekdays to activities such as household chores, probably trying to gain leisure time for nonworking days 36 . In our sample, only slight differences were observed in commuting time according to multiple job holding. However, teachers working in several schools used more frequently individual motorized transportation than teachers with exclusive dedication (results not shown), which could reflect the need to save time in the displacements between schools. However, this hypothesis is speculative and should be further investigated.

Fourth, the results of self-certified sickness absence differed according to gender. Among women working standard hours and men working moderately long hours in several schools, positive associations were found with self-certified sickness absence. Our first hypothesis was that women would be 
Number, prevalence and association of the joint effect of weekly paid working hours and multiple job holding on medically certified sickness absence, according to sex. Educatel Study, 2015-2016.

\begin{tabular}{|c|c|c|c|c|c|c|}
\hline Main independent variable, by sex & $\mathbf{n}$ & $\%$ & PRc & $95 \% \mathrm{Cl}$ & PRa & $95 \% \mathrm{Cl}$ \\
\hline \multicolumn{7}{|l|}{ Women } \\
\hline \multicolumn{7}{|c|}{ Number of schools and paid working hours } \\
\hline \multicolumn{7}{|l|}{ Working in one school (hours) } \\
\hline $35-40$ & 181 & 22.0 & 1.00 & & 1.00 & \\
\hline$<35$ & 161 & 17.2 & 0.78 & $0.65-0.95$ * & 0.84 & $0.70-1.03$ \\
\hline $41-50$ & 11 & 20.0 & 0.91 & $0.53-1.57$ & 0.93 & $0.54-1.60$ \\
\hline$>50$ & 11 & 23.4 & 1.06 & $0.62-1.81$ & 1.07 & $0.63-1.83$ \\
\hline \multicolumn{7}{|c|}{ Working in more than one school (hours) } \\
\hline $35-40$ & 121 & 22.8 & 1.04 & $0.85-1.27$ & 1.10 & $0.89-1.36$ \\
\hline$<35$ & 58 & 19.9 & 0.90 & $0.69-1.18$ & 0.99 & $0.75-1.30$ \\
\hline $41-50$ & 55 & 23.7 & 1.08 & $0.83-1.40$ & 1.14 & $0.87-1.49$ \\
\hline$>50$ & 86 & 28.1 & 1.28 & $1.02-1.59$ * & 1.30 & $1.03-1.63 *$ \\
\hline \multicolumn{7}{|l|}{ Men } \\
\hline \multicolumn{7}{|c|}{ Number of schools and paid working hours } \\
\hline \multicolumn{7}{|l|}{ Working in one school (hours) } \\
\hline $35-40$ & 64 & 18.1 & 1.00 & & 1.00 & \\
\hline$<35$ & 72 & 15.0 & 0.83 & $0.61-1.13$ & 0.91 & $0.66-1.23$ \\
\hline $41-50$ & 7 & 22.6 & 1.25 & $0.63-2.48$ & 1.31 & $0.67-2.57$ \\
\hline$>50$ & 2 & 9.1 & 0.50 & $0.13-1.91$ & 0.48 & $0.12-1.82$ \\
\hline \multicolumn{7}{|c|}{ Working in more than one school (hours) } \\
\hline $35-40$ & 59 & 18.0 & 0.99 & $0.72-1.37$ & 1.04 & $0.75-1.44$ \\
\hline$<35$ & 43 & 19.6 & 1.08 & $0.76-1.53$ & 1.21 & $0.85-1.72$ \\
\hline $41-50$ & 40 & 20.9 & 1.16 & $0.81-1.65$ & 1.17 & $0.82-1.67$ \\
\hline$>50$ & 69 & 25.4 & 1.40 & $1.047-1.89$ * & 1.41 & $1.04-1.92$ * \\
\hline
\end{tabular}

95\% Cl: 95\% confidence interval; PRa: adjusted prevalence ratio (for age, type of contract and salary); PRc: crude prevalence ratio.

* $\mathrm{p}$-value $<0.05$.

more affected by multiple job holding or longer working hours due to the different time patterns of paid work among genders. However, the associations were not altered after adjusting by the variables related to volume of unpaid care work, like taking care of children, hours of domestic work or civil status (results not shown). Some studies have highlighted that the traditional variables to measure work-family conflict might not be able to capture the complexity of the burden resulting in combining work and care responsibilities ${ }^{37}$. Nevertheless, we have not been able to prove this hypothesis in our study with the available variables. We therefore suggest that women working standard hours in several schools might be suffering all the disadvantages of working in several schools, but none of the benefits, such as greater salaries. Additionally, we found that women working standard hours in several schools who experienced self-certified sickness absence reported more frequently having sleeping problems because of being worried than their counterparts working moderately long working hours (69\% and 63\%, respectively). Several studies had already highlighted the relationship between sleeping problems and self-certified sickness absence, which might be the result of a need to restore from insufficient sleep 38 . However, this hypothesis is still undeveloped and should be contrasted with further studies assessing the gender differences of the relationship between the joint effect of multiple job holding and paid working hours with sickness absence.

Finally, we only found an association with medically certified sickness absence among teachers working very long working hours in several schools. In this sense, it is possible that findings on selfcertified sickness absence and medically certified sickness absence need different interpretations. 
It has been suggested that self-certified sickness absences and medically certified sickness absences need to be analyzed separately. Self-certified sickness absence is sensitive to subjectivity and could therefore reflect minor health problems. In fact, several studies have considered that self-certified sickness absence could serve as a coping mechanism for adverse working conditions, such as long working hours or excessive workload 39 . Thus, self-certified sickness absence could reflect a specific organizational culture within a workplace on a larger extent than health problems. In contrast, it has been observed that medically certified sickness absence is a strong predictor of all-cause mortality and specific causes of early retirement 40,41 . Therefore, our findings suggest that teachers working very long weekly hours in several schools might develop severe health problems, constituting a risk factor for temporary and permanent disability, and early retirement.

This study has some limitations. Firstly, since it is a cross-sectional study, we cannot discard reverse causation, although it is unlikely that teachers working longer hours are those who present poorer health status. Secondly, we did not include the educational level that teachers imparted, because around half of the teachers were teaching in several levels simultaneously. Finally, this survey gathered no information on the number of sickness absence spells during the previous 12 months, which would have enriched the discussion.

Likewise, the study presents several strengths. Firstly, it is based on a representative sample of all the Brazilian basic education teachers. Secondly, the separate use of self-certified and medically certified sickness absence provides information about the severity of the health problem and the organizational functioning of the schools. Lastly, this is the first study assessing the joint effect of multiple job holding and working hours on health outcomes, using a comprehensive approach for the classification of working hours.

In conclusion, working longer hours in several schools is a risk factor for work absence due to health problems. The teacher's wellbeing is a crucial factor affecting the quality of education. Sickness absence constitutes key indicators to assess this important social and economic problem. Future actions directed to improve the working and employment conditions of teachers are needed.

\section{Contributors}

L. Rodríguez-Loureiro participated in the discussion of the analysis strategy, cleaned and prepared the dataset for the analysis, carried out the analyses, participated in the interpretation and discussion of the results, drafted the manuscript and completed its final version to be published. L. Artazcoz participated in the discussion of the analysis strategy, made substantial contributions in the interpretation and discussion of the results, and revised and approved the final version of the manuscript to be published. M. López-Ruiz participated in the discussion of the analysis strategy, in the interpretation and discussion of the results, and revised and approved the final version of the manuscript to be published. A. A. Assunção participated in the conception and design of the study, in the selection of the sample, in the interpretation and discussion of the results, and revised and approved the final version of the manuscript to be published. F. G. Benavides participated in the discussion of the analysis strategy, made substantial contributions in the interpretation and discussion of the results, and revised and approved the final version of the manuscript to be published.

\section{Additional informations}

ORCID: Lucía Rodríguez-Loureiro (0000-00030092-3748); Lucía Artazcoz (0000-0002-63005111); María López-Ruiz (0000-0003-3453-0408); Ada Ávila Assunção (0000-0003-2123-0422); Fernando G. Benavides (0000-0003-0747-2660)

\section{Acknowledgments}

To Department of School Systems Linkage of the Brazilian Ministry of Education; the Brazilian National Institute for Educational Studies and Research "Anísio Teixeira” (INEP); and the Brazilian National Research Council (CNPq) for the financial support. 


\section{References}

1. van der Hulst M. Long workhours and health Scand J Work Environ Health 2003; 29:17188.

2. Virtanen M, Heikkilä K, Jokela M, Ferrie J, Batty G, Vahtera J, et al. Long working hours and coronary heart disease: a systematic review and meta-analysis. Am J Epidemiol 2012; 176:586-96.

3. Bannai A, Tamakoshi A. The association between long working hours and health: a systematic review of epidemiological evidence. Scand J Work Environ Health 2014; 40:5-18.

4. Kivimäki M, Jokela M, Nyberg S, Singh-Manoux A, Fransson E, Alfredsson L, et al. Long working hours and risk of coronary heart disease and stroke: a systematic review and metaanalysis of published and unpublished data for 603838 individuals. Lancet 2015; 386:173946.

5. Ganster DC, Rosen CC, Fisher GG. Long working hours and well-being: what we know, what we do not know, and what we need to know. J Bus Psychol 2016; 33:25-39.

6. Artazcoz L, Cortès I, Escribà-Agüir V, Bartoll $\mathrm{X}$, Basart H, Borrell C. Long working hours and health status among employees in Europe: between-country differences. Scand J Work Environ Health 2013; 39:369-78.

7. Artazcoz L, Cortès I, Benavides FG, EscribàAgüir V, Bartoll X, Vargas H, et al. Long working hours and health in Europe: gender and welfare state differences in a context of economic crisis. Health Place 2016; 40:161-8.

8. Marucci-Wellman HR, Willetts JL, Lin TC, Brennan MJ, Verma SK. Work in multiple jobs and the risk of injury in the US working population. Am J Public Health 2014; 104:134-42.

9. Marucci-Wellman HR, Lombardi DA, Willetts JL. Working multiple jobs over a day or a week: short-term effects on sleep duration. Chronobiol Int 2016; 33:630-49.

10. Bouwhuis S, Garde AH, Geuskens GA, Boot CRL, Bongers PM, van der Beek AJ. The longitudinal association between multiple job holding and long-term sickness absence among Danish employees: an explorative study using register-based data. Int Arch Occup Environ Health 2017; 90:799-807.

11. Abramo L. Inserção das mulheres no mercado de trabalho na América Latina: uma força de trabalho secundária? [Doctoral Dissertation]. São Paulo: Faculdade de Filosofia, Letras e Ciências Humanas, Universidade de São Paulo; 2007.

12. Artazcoz L, Cortès I, Borrell C, Escribà-Agüir V, Cascant L. Gender perspective in the analysis of the relationship between long workhours, health and health-related behavior. Scand J Work Environ Health 2007; 33:34450.

13. Assunção AA, Oliveira DA. Intensificação do trabalho e saúde dos professores. Educação \& Sociedade 2009; 30:349-72.
14. Brasil. Lei no 11.738 , de 16 de julho de 2008. Regulamenta a alínea "e" do inciso III do caput do art. 60 do Ato das Disposições Constitucionais Transitórias, para instituir o piso salarial profissional nacional para os profissionais do magistério público da educação básica. Diário Oficial da União 2008; 17 jul.

15. Departamento Intersindical de Estatística e Estudos Socioeconômicos. Transformações recentes no perfil do docente das escolas estaduais e municipais de educação básica. http:// www.dieese.org.br/notatecnica/2014/nota Tec141DocentesPnadvf.pdf (accessed on 26/ Oct/2018)

16. Oliveira DA, Dourado LF, Cabral Neto A Cury CRJ, Oliveira JF, Pinto JMR, et al. Por um Plano Nacional de Educação (2011-2020) como política de Estado. Rev Bras Educ 2011; 16:483-92.

17. Organisation for Economic Co-operation and Development. TALIS 2013. Results: an international perspective on teaching and learning. Paris: OECD Publishing; 2014.

18. Oliveira D, Vieira L. Condições do trabalho docente: uma análise a partir de sete estados brasileiros. In: Oliveira D, Vieira L, organizadores. Trabalho na educação básica: a condição docente em sete estados brasileiros. Belo Horizonte: Fino Traço Editora; 2012. p. 153-90.

19. Matijascic M. Professores da Educação Básica no Brasil: condições de vida, inserção no mercado de trabalho e remuneração. http://repo sitorio.ipea.gov.br/bitstream/11058/7929/1/ td_2304.pdf (accessed on 26/Oct/2018).

20. Vieira MT, Claro RM, Assunção AA. Sample design and participation in the Educatel Study. Cad Saúde Pública 2019; 35 Suppl 1:e00167217.

21. Gimeno D, Benavides FG, Benach J, Amick BC. Distribution of sickness absence in the European Union countries. Occup Environ Med 2004; 61:867-9.

22. Ferrie JE, Kivimäki M, Head J, Shipley MJ, Vahtera J, Marmot MG. A comparison of selfreported sickness absence with absences recorded in employers' registers: evidence from the Whitehall II study. Occup Environ Med 2005; 62:74-9.

23. Marmot M, Feeney A, Shipley M, North F, Syme SL. Sickness absence as a measure of health status and functioning: from the UK Whitehall II study. J Epidemiol Community Health 1995; 49:124-30.

24. Szklo M, Nieto F. Defining and assessing heterogeneity of effects: interaction. In: Nieto F, Moore M, editors. Epidemiology beyond the basics. Gaithersburg: Aspen Publishers; 2000. p. 211-53

25. Niedhammer I, Chastang JF, Sultan-Taïeb H, Vermeylen G, Parent-Thirion A. Psychosocial work factors and sickness absence in 31 countries in Europe. Eur J Public Health 2013; 23:622-9. 
26. Lesuffleur T, Chastang J, Sandret N, Niedhammer I. Psychosocial factors at work and sickness absence: results from the French National SUMER Survey. Am J Ind Med 2014; 57:695708.

27. Artazcoz L, Benach J, Borrell C, Cortès I. Social inequalities in the impact of flexible employment on different domains of psychosocial health. J Epidemiol Community Health 2005; 59:761-7.

28. Koukoulaki T. New trends in work environment: new effects on safety. Saf Sci 2010; 48:936-42.

29. Batista JB, Carlotto MS, Coutinho AS, Pereira DA, Augusto LG. O ambiente que adoece: condições ambientais de trabalho do professor do ensino fundamental. Cad Saúde Colet (Rio J.) 2010; $18: 234-42$

30. Tabeleão VP, Tomasi E, Neves SF. Qualidade de vida e esgotamento profissional entre docentes da rede pública de Ensino Médio e Fundamental no Sul do Brasil. Cad Saúde Pública 2011;27:2401-8

31. Pereira EF, Teixeira CS, Andrade RD, Silva -Lopes A. O trabalho docente e a qualidade de vida dos professores na educação básica. Rev Saúde Pública 2014; 16:221-31.

32. Artazcoz L, Borrell C, Benach J. Gender inequalities in health among workers: the relation with family demands. J Epidemiol Community Health 2001; 55:639-47.

33. Artazcoz L, Cortés I, Puig-Barrachina V, Benavides FG, Escribà-Agüir V, Borrell C. Combining employment and family in Europe: the role of family policies in health. Eur J Public Health 2014; 24:649-55.

34. Bamberry L, Campbell I. Multiple job holders in Australia: motives and personal impact. Aust Bull Labour 2012; 38:293-314
35. López-Ruiz M, Benavides F, Vives A, Artazcoz L. Informal employment, unpaid care work, and health status in Spanish-speaking Central American countries: a gender-based approach. Int J Public Health 2017; 62:209-18.

36. Marucci-Wellman HR, Lin T-C, Willetts JL, Brennan MJ, Verma SK. Differences in time use and activity patterns when adding a second job: implications for health and safety in the United States. Am J Public Health 2014; 104:1488-500.

37. Nilsen W, Skipstein A, Østby KA, Mykletun A. Examination of the double burden hypothesis: a systematic review of work-family conflict and sickness absence. Eur J Public Health 2017; 27:465-71.

38. Rahkonen O, Lallukka T, Kronholm E, Vahtera J, Lahelma E, Laaksonen M. Sleep problems and sickness absence among middle-aged employees. Scand J Work Environ Health 2012; 38:47-55.

39. Ala-Mursula L, Vahtera J, Kouvonen A, Väänänen A, Linna A, Pentti J, et al. Long hours in paid and domestic work and subsequent sickness absence: does control over daily working hours matter? Occup Environ Med 2006; 63:608-17.

40. Vahtera J, Pentti J, Kivimäki M. Sickness absence as a predictor of mortality among male and female employees. J Epidemiol Community Health 2004; 58:321-6.

41. Kivimäki M, Forma P, Wikström J, Halmeenmäki T, Pentti J, Elovainio M, et al. Sickness absence as a risk marker of future disability pension: the 10-town study. J Epidemiol Community Health 2004; 58:710-1. 


\section{Resumen}

El objetivo de este estudio fue evaluar el efecto conjunto de las horas laborales pagadas semanalmente y pluriempleo, en relación con las ausencias por enfermedad, según el por sexo, entre profesores de educación básica en Brasil. Este estudio se llevó a acabo sobre una encuesta de una muestra representativa de 5.116 profesores activos de educación básica en Brasil, entre 2015 y 2016 (Estudio Educatel). Creamos una variable dummy para evaluar el efecto conjunto de las horas laborales pagadas semanalmente [estándar (35-40 horas); a tiempo parcial (< 35 horas); moderadamente largas (4150 horas); $y$ muy largas (> 50 horas)] y el pluriempleo (trabajando en varias escuelas no/si). Estar trabajando 35-40h en una escuela fue la categoría de referencia. Se realizaron modelos de regresión de Poisson con varianza robusta para obtener la razón de prevalencia $(R P)$ e intervalos de $95 \%$ de confianza (IC95\%) de la asociación con las ausencias por enfermedad justificadas personalmente $y$ las ausencias por enfermedad con certificado médico. Los modelos fueron ajustados por edad, tipo de contrato y salario, y estratificados por sexo. Las asociaciones significativas con ausencias por enfermedad se encontraron sólo entre profesores que trabajaban en más de una escuela. Las asociaciones con las ausencias por enfermedad justificadas personalmente se hallaron entre mujeres con horas de trabajo estándar y hombres con horas de trabajo moderadamente largas, $y$ para ambos, mujeres $y$ hombres trabajando > 50 horas (RP: 1,21, IC95\%: 1,09-1,35; RP: 1,40, IC95\%: 1,18-1,66; respectivamente). Las asociaciones con las ausencias por enfermedad con certificado médico se hallaron entre profesores trabajando $>50$ horas, entre mujeres (RP: 1,30, IC95\%: 1,03-1,63) y hombres (RP: 1,41, IC95\%: 1,04-1,92). Los profesores que trabajan más horas en varias escuelas podrían estar sufriendo problemas de salud, ocasionando ausencias laborales.

Maestros; Salud Laboral; Absentismo; Factores Socioeconómicos

\section{Resumo}

O estudo teve como objetivos avaliar o efeito conjunto das horas semanais de trabalho remunerado e do fato de ter vários empregos sobre o absenteísmo por motivo de doença entre professores de ensino básico, desagregado por sexo, no Brasil. Este estudo teve como base um inquérito realizado em uma amostra representativa de 5.116 professores de ensino básico em atividade no Brasil entre 2015 e 2016 (Estudo Educatel). Criamos uma variável dummy para avaliar o efeito conjunto das horas semanais de trabalho remunerado [padrão (35-40 horas); tempo parcial (< 35 horas); semana de trabalho moderadamente longa (41-50 horas) e muito longa (> 50 horas)] e múltiplos empregos (trabalho em mais de uma escola - não/sim). A categoria de referência foi o trabalho em uma única escola $d u$ rante 35-40 horas semanais. Realizamos modelos de regressão de Poisson com variância robusta para obter razões de prevalência $(R P)$ e intervalos de confiança de 95\% (IC95\%) para a associação com ausência no trabalho por motivo de saúde alegado pelo próprio indivíduo, e com atestado médico. Os modelos foram ajustados para idade, tipo de vínculo de trabalho e salário, e estratificados por sexo. Os resultados só mostraram associações significativas com absenteísmo por motivo de saúde em professores que trabalhavam em mais de uma escola. Foram observadas associações com ausência por motivo de saúde alegado pelo próprio indivíduo em mulheres com semana de trabalho padrão e em homens com semana moderadamente longa, e em mulheres e homens que trabalhavam mais de 50 horas por semana (RP: 1,21, IC95\%: 1,09-1,35; RP: 1,40, IC95\%: 1,18-1,66; respectivamente). Foram encontradas associações com ausência com atestado médico entre professores que trabalhavam mais de 50 horas por semana, em mulheres (RP: 1,30, IC95\%: 1,03-1,63) e homens (RP: 1,41, IC95\%: 1,04-1,92). Professores brasileiros que trabalham horas longas em várias escolas podem sofrer problemas de saúde, levando ao absenteísmo.

Professores Escolares; Saúde do Trabalhador; Absenteísmo; Fatores Socioeconômicos
Submitted on 25/Apr/2018

Final version resubmitted on 26/Oct/2018

Approved on 05/Nov/2018 